\title{
The Role of Students in Responding to the Transparency of COVID 19 Data in Media
}

\author{
Cindenia Puspasari ${ }^{1}$, Ade Muana Husniati $^{1}$, Ainol Mardhiah $^{1 *}$, Khaidir $^{2}$ \\ ${ }^{1}$ Department of Communication Science, FISIP, Universitas Malikussaleh \\ ${ }^{2}$ Chair of the Advocacy of the Indonesian Journalists Alliance (AJI) \\ *Correspondence email : inol_mardhiah@yahoo.co.id
}

\begin{abstract}
COVID 19 is a contagious disease caused by a newly discovered type of coronavirus that has become a pandemic. The new virus and the disease it causes were not known before the outbreak in Wuhan, China, in December 2019. The virus which was later named Covid 19 spread throughout the world. Until now, the virus, which was originally transmitted from wild animals to humans, has infected millions of people in as many as 60 countries. Several types of coronavirus are known to cause respiratory infections in humans ranging from colds to more serious coughs such as Middle East Respiratory Syndrome (MERS) and Severe Acute Respiratory Syndrome (SARS). Therefore, one of the treatment of health problems in preventing the transmission of Covid 19 is the principle of data transparency and the importance of students' role in responding to data transparency for the development and promotion of health communication in the society. Therefore, the role of students in responding to data transparency in the media can increase public awareness in dealing with the outbreak caused by the corona virus so that people can be more preventive and can be motivated to be able to increase alertness and body resilience.
\end{abstract}

Keywords: Transparency principle in media, Students' role, Covid 19

\section{INTRODUCTION}

Corona Virus is a serious contagious disease because it can cause death and has become a pandemic outbreak. Corona virus is not a hoax. Corona virus is a new virus and the disease it causes was not known before the outbreak began in Wuhan, China, in December 2019. The virus which was later named Covid 19 spread throughout the world. Until now, the virus, which was originally transmitted from wild animals to humans, has infected millions of people in various countries. Now, the world is experiencing a pandemic (disease outbreak) from the corona virus, including Indonesia. According to the Central Statistics Agency (BPS) 2019, Indonesia has a population projected to have reached 270 million. As the fourth most populous country in the world, it is undeniable that the Covid 19 outbreak has also been widespread. This is because the death rate has increased in the world, including in Indonesia. Head of the Ministry of Health's Information Data Center, Didik Budianto (Mashabi, April 2020) stated that the openness of data can increase public awareness in dealing with outbreaks caused by the corona virus so that the public can be more preventive.
The Indonesian government in dealing with this outbreak has implemented a policy on the application of the Covid 19 Protocol. It is necessary to have transparency of data from the government to the public so that people know the spread pattern of this worldwide disease outbreaks. The communication that is carried out here is that the government as a communicator in conveying messages related to Covid 19 data and the citizens as communicants can get feedback on the message delivery. This means that the disclosure of data and information resulting from the application of the transparency principles of Covid 19 data run by the government will be able to influence the making of advanced policy related to Covid 19 and can be the subject of study in the decision making of the outbreak which has already applied.

\section{TRANSPARENCY OF COVID 19 DATA IN MEDIA}

The positive implication of data transparency in handling the Covid 19 outbreak is participation. This is because people have the freedom to act as citizen with the openness of public information through various media. The positive thing is that today's society can be active 
and critical in monitoring government actions that is subtly manifested in public dialogue. So that the public needs to understand what attitudes can and cannot be done in supervising the prevention of Covid 19. Therefore, the role of students is needed to achieve participation in the implementation of Covid 19 data transparency run by the government so that feedback is achieved on the delivery of policies in Covid 19 handling.

The purpose of data transparency in media and students' participation is to providing understanding or education to the public based on data submitted by the Government and the media about Covid 19. And to build mutual trust between the government and the public where the government must provide accurate information to the public in need. Meanwhile, the objective of Covid 19 data transparency can be felt by the community as a whole. Therefore, it can prevent deviations as early as possible through public awareness with social control, avoid communication errors and differences in perceptions in understanding the Covid 19 handling and encourage people to learn to be responsible for what the government has suggested for coping with the prevention of Covid 19.

\subsection{Principle of Data Transparency}

The government as the organizer and executor of state affairs in realizing transparency can start from public openness. Based on Act Number 14 of 2008 concerning Openness of Public Information, it is explained the importance of public openness to achieve transparent, effective, efficient, and accountable state participation and governance. This is because the openness of public information and data transparency can form a check and balance and make it easier for the public to know rational actions as social control by comparing the existing value systems.

Thus, how is the handling of the Covid 19 issue and the dynamics of the information flow on social media? It turns out that the use of this media tool is very helpful for someone in solving their health problems. It is actually important to develop and promote information with data transparency. Therefore, this is a study of health communication. The role of media can also increase public awareness in dealing with the outbreak caused by the corona virus, so that people can be more preventive and can be motivated to be able to increase alertness and body resilience.

Transparency is a principle that guarantees access or freedom for everyone to obtain information about governance, namely the information about policies, the process of making and implementing and the results achieved. According to Hafiz (2000), transparency is defined as openness and honesty to society based on the consideration that the public has the right to know openly and thoroughly the accountability of government in the resources entrusted to it and its compliance with laws and regulations. Thus, it can be concluded that transparency is a principle that guarantees the right of the public to obtain access to correct, honest, and non-discriminatory information regarding the implementation related to the handling of Covid 19 outbreak in Indonesia.

There are three indicators in measuring data transparency in public services. First, the level of openness to Covid 19 information process. Second, transparency in regulations and service procedures that are easily understood by the public regarding Covid 19. Third, transparency of services through the ease of information access about various aspects of government program implementation regarding instructions on overcoming Covid 19 pandemic.

There are several strategies so that transparency and public participation in campaigning for government programs on Covid 19 can go hand in hand, among others, first, identifying the role of community. This aspect is important in realizing transparency as a stimulus in encouraging public participation such as the 6 prevention for Covid 19 campaign. Second, increasing the role of external supervisory agencies, the task force. Third, the commitment from the government in protecting its people while still providing transparency of Covid 19 data.

\subsection{The Transparency of Covid 19 Data}

The spread of the Covid 19 virus infection in Indonesia is increasingly widespread to date. Covid 19 cases have spread in 34 provinces consist of 514 regencies-cities. On Monday, March 2, 2020 the President of the Republic of Indonesia Joko Widodo announced that two Indonesian citizens had contracted the corona virus, a 31-year-old woman and a 64-year-old elderly woman. In midJune 2020, cases of the spread of Covid 19 infection continued to increase and made Indonesia the country with the highest number of cases in Southeast Asia. 


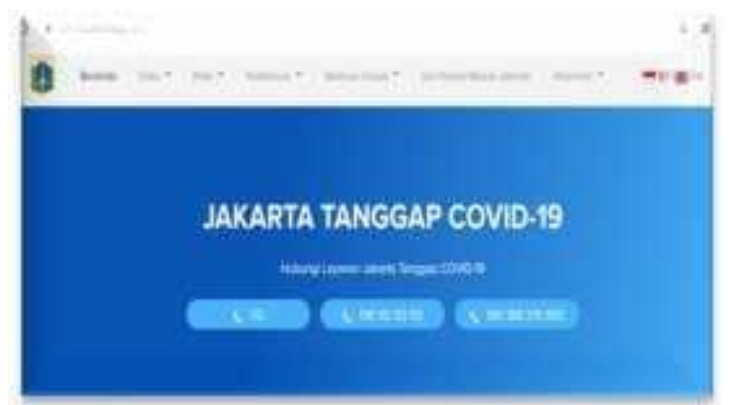

Figure 1. The transparency of Covid 19 data from the Jakarta website because Jakarta is the epicenter of the Corona Virus spread.

As shown in the following monitoring data, which is shown on the latest site update on October 14, 2020 in Figure 2.

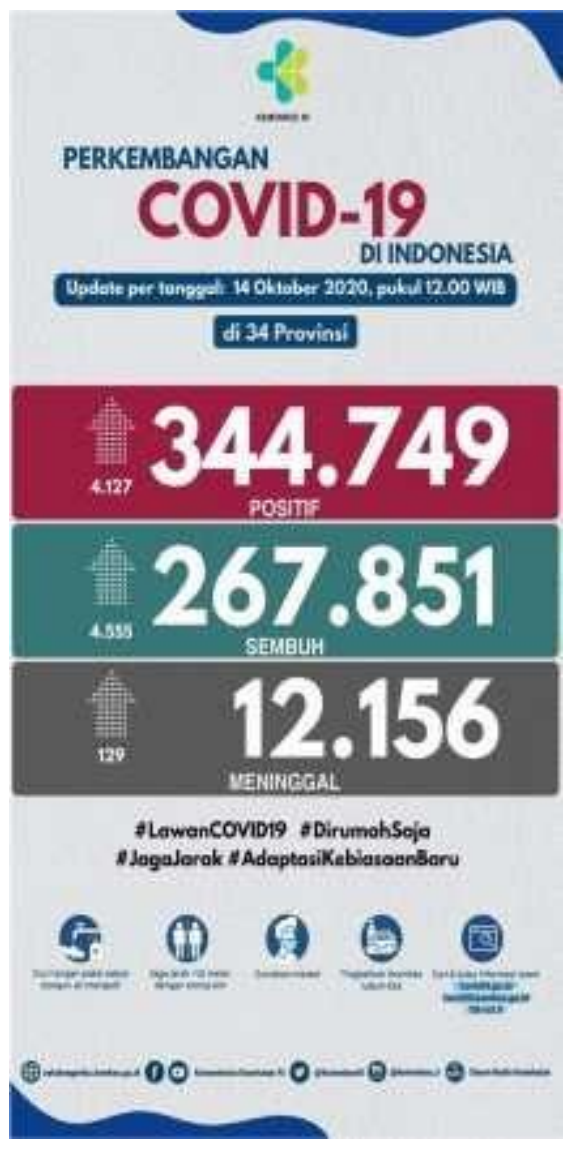

Figur 2. The data of Corona 19 virus positive cases on October 15, 2020, increased by 4411 to 349.160 people. The number of recovered patients increased by 5810 to 273.661 people. Death cases increased by 112 to 2.268 .

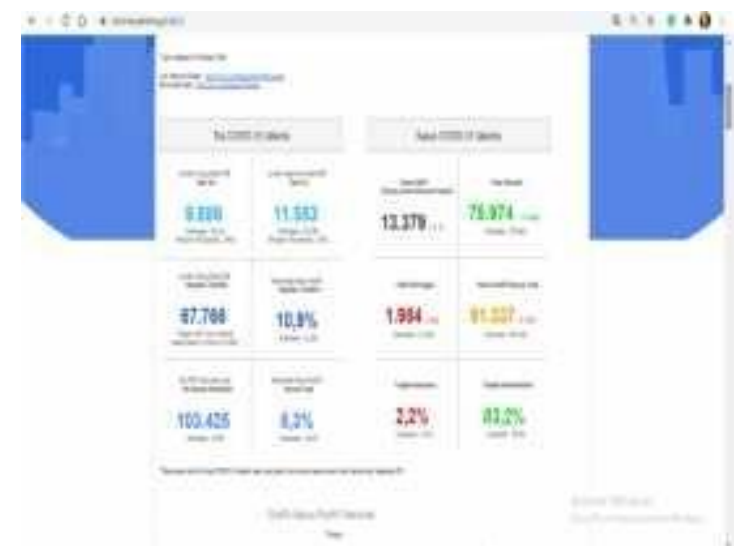

Figure 3. The latest data from Jakarta as Jakarta is the epicentrum of this pandemic spread, data updated on corona.jakarta.go.id website.

Data submitted by the Government regarding Covid 19. In Aceh, the Covid 19 data is continuously updated based on data from Covid 19 Task Force.

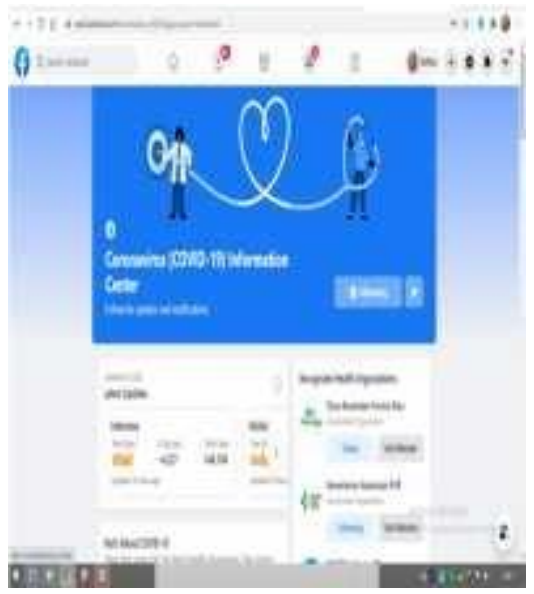

Figure 4. Below is also a Covid 19 data transparency from the Facebook social media network on the Covid 19 Information Center page.

\subsection{Media}

The role of students in responding to the transparency of Covid 19 data in governmentrun media is very important so the information does not become disinformation or hoax. Firstly, as the students have to support the Government campaign program to handling Covid 19. The second, students have to providing understanding or education to the public based on data submitted by the Government and the media about Covid 19 and 
educated the public in active communication with factual data.

In Tamburaka's book (2013), Baran and Dennis (2010) state that media literacy is a series of media literacy activities, namely the media literacy movement designed to increase individual control over the media they use to send and receive messages. Then in this case media literacy is seen as a skill that can develop in a series where we are not always literate to media in all situations, every time and to all media.

Technological developments have an impact on the development of media literacy. One of them is the birth of new media, namely digital media or the internet. Now the internet is no longer something rare but is now very easy to access anytime and anywhere. Apart from that, the advantage of the internet here is that it has a wide and unlimited range of access to information.

By studying media literacy, the main benefit is to make us "media literate" individuals. This means that we become individuals who understand, have extensive knowledge, are able to analyze, assess, and are able to have a critical opinion of the information or media messages we get. So that we can always take a stand on a certain issue or problem wisely and not easily get carried away and be led by opinions towards negative things.

\section{THE ROLE OF STUDENTS IN SOCIETY IN RESPONDING TO THE TRANSPARENCY OF COVID 19 DATA}

According to the Indonesian Dictionary (KBBI), a student is someone who studies in tertiary institutions, within the educational structure and holds the highest educational status among others. Students have a lot of potential and opportunities so that students have an important role to play in contributing to society. The 5 roles of students in society including as agent of change, guardian of value, iron stock, moral force and social control.

This is where the students as agents of change plays a role as a community promoter to become the front guard in making changes to a better direction by using their knowledge, ideas and knowledge. This means that students must become supporters and drivers of government programs regarding Covid 19 which have been campaigned through the media. The program is the five important things to prevent Covid 19 and it has become the latest Covid 19 Protocol.

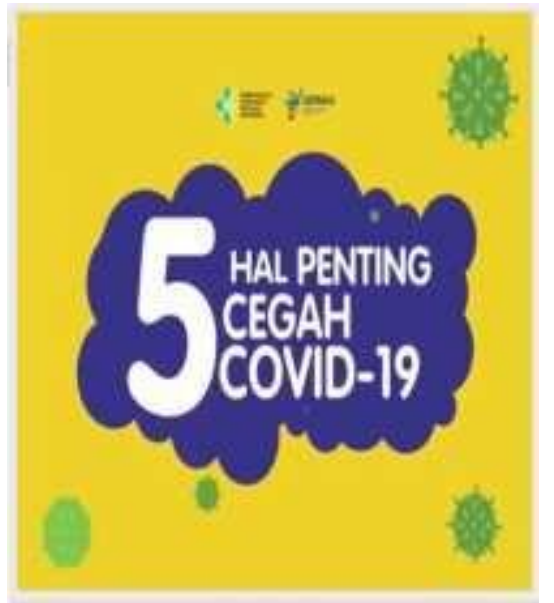

Figure 5. The Covid 19 Audio Visual Campaign

The picture above (Figure 5.) is campaigning for the Covid 19 protocol during the New Normal program. Five important things to prevent Covid 19 including wash your hands frequently with soap, stay at home, keep your distance and avoid crowds, do not shake hands, wear masks when you are sick or in public places.

Students as guardians of value mean that students are keepers and spreaders of values in society, namely the values of honesty, justice, mutual cooperation, integrity, empathy and so on. Students in supporting government programs in achieving transparency of COVID 19 data must become guardians and disseminators of information related to Covid 19 data, so that the public does not receive fabricated information about Covid 19 or known as an infodemic. The objective is to provide understanding or education to the public based on data submitted by the Government and the media about Covid 19 while still paying attention to the stigma and data in the media. Thus, there is no mistake in providing information to the public.

In dealing with Covid-19, the Indonesian government, in various Provinces and Regions, has drawn criticism and is still considered slow and not transparent when releasing data to the public including budget transparency data that has been spent on handling Covid 19 for both health and economic development. In order to respond to this, students are required to access the data through the government website or access it by examining Act Number 14 of 2008 concerning Openness of Public Information. Article $28 \mathrm{~F}$ of the 1945 Constitution of the Republic of Indonesia states that everyone has the right to communicate and obtain information to develop their personal and social 
environment, as well as the right to seek, to obtain, to own and to store information using all available channels.

Students as an iron stock are students as the nation's next generation who become assets, reserves and hopes of the nation in the future. They are expected to have the ability and commendable behavior to be able to replace previous generations in the government structure. It is hoped that they can apply the five important things in conveying the Covid 19 protocol to the public and always apply it in front of the community so that people understand the importance of implementing the Covid 19 protocol in the current era.

Then, students play a role as moral force in society. As an academic person, students' intellectual level is equal to their morality level. They are expected to be examples and drivers of moral improvement in society. By applying the Covid 19 protocol every day, the role of students will be seen in educating the public in supporting government programs in preventing Covid 19. Thus, it can be said that "Smart people wear masks".

And last, students as social control for the community and the nation to become a bridge for the community to guard the running of the government bureaucracy in order to create better development for the country. They have active communication (critical) with the delivery of factual data and become a bridge for the community to oversee government programs related to Covid 19, in order to uphold information transparency in government.

\section{CONCLUSION}

Information openness between the government and the community is mediated by the importance of students' role in obtaining Covid 19 data transparency and implementing the Covid 19 protocol. Therefore, the success of the policy on the Covid 19 protocol campaign must also synergize between government, community, office holders, students and youth to stop the spread of Covid 19. Students must show empathy so that they can help campaigning for the dangerous effects of Covid 19 by using mass media, digital media and social media through the application of the Covid 19 protocol.

Students must be able to urge the government to be transparent regarding the Covid 19 data by using the media. The role of the media is very important to invite all components of society to participate in overcoming Covid 19 by spreading correct information. As WHO Director General, Tedros Adhanom Ghebreyesus at The Munich Security Conference on Feb 15, said, "We're not just fighting an epidemic, we're fighting an infodemic".

Thus, with the role of students in responding to the transparency of Covid 19 data, it can minimize the spread of the Covid 19 outbreak. This is because Covid 19 also has a detrimental impact on society in an economic and social perspective.

\section{REFERENCES}

[1] Hafiz, A. 2000 "Akuntansi, Transparansi, dan Akuntabilitas Keuangan Publik", Yogyakarta: BPFE UGM

[2] Husna, F.A. 2017. Peran Penting Mahasiswa pada Untuk Masyarakat. https://www.kompasiana.com/finaatifa/5a031 415ed967e56e164c172/peran-pentingmahasiswa-untuk-masyarakat?page $=$ all diakses pada tanggal 15 Oktober 2020, 13.30 WIB.

[3] Mashabi, Sania. April 2020. Ini Manfaat Keterbukaan Data Penanganan Covid 19 untuk Masyarakat. https://nasional.kompas.com/read/2020/04/28/ 15151891/ini-manfaat-keterbukaan-datapenanganan-covid-19-untukmasyarakat?page $=$ all, diakses pada 1 Oktober 2020 jam

[4] Tamburaka, Apriadi. 2013. Literasi Media: Cerdas Bermedia Khalayak MediaMassa. Jakarta: Rajawali Press.

[5] https://www.covid19.go.id dan Kementerian Kesehatan (Kemenkes) melalui laman https://www.kemkes.go.id/.

[6] Undang-Undang Nomor 14 Tahun 2008 tentang Keterbukaan Informasi Publik. 